Historia Contemporánea 57, 2018: 523-558

ISSN: $1130-2402-$ e-ISSN: $2340-0277$

DOI: $10.1387 /$ hc. 17811

\title{
EL ÚLTIMO ROMÁNTICO DE NUESTRA POLÍTICA. FERNANDO SOLDEVILLA RUIZ Y EL ESPAÑOLISMO IMPARCIAL
}

THE LAST ROMANTIC OF OUR POLITICS. FERNANDO SOLDEVILLA RUIZ AND IMPARTIAL «ESPAÑOLISMO»

\author{
Josep Pich Mitjana \\ ORCID: https://orcid.org/0000-0002-2432-3926 \\ David Martínez Fiol \\ ORCID: https://orcid.org/0000-0001-5844-3232 \\ José Contreras Ruiz \\ ORCID: https://orcid.org/0000-0001-8279-2619 \\ Grup de Recerca en Estats Nacions i Sobiranies (GRENS) \\ de la Universitat Pompeu Fabra-España
}

Recibido el 2-5-2017 y aceptado el 26-12-2017

Resumen: Este artículo es una aproximación a la trayectoria de Fernando Soldevilla Ruiz (1854-1931) escritor relativamente prolífico y periodista respetado, con una larga trayectoria en diarios de la relevancia de El Imparcial o $\mathrm{La}$ Correspondencia de España. De orígenes humildes fue un dirigente del liberalismo español. Ejerció de gobernador civil, siendo elegido por dos veces diputado a Cortes. En 1913, con cincuenta y nueve años, fue nombrado jefe de la Inspección Mercantil y de Seguros, detentando este cargo hasta su jubilación en 1929. Se caracterizó por ser un acérrimo defensor de una España políticamente centralizada y culturalmente uniformizada, sosteniendo un discurso de un marcado nacionalismo español. Su retórica españolista se tradujo en sus sistemáticas críticas hacia el catalanismo y el nacionalismo vasco, movimiento que identificaba como bizcaitarra. Soldevilla era conocido por ser el autor de El Año 
político anuario político publicado de forma ininterrumpida durante las primeras décadas del siglo $\mathrm{xx}$.

Palabras clave: Fernando Soldevilla Ruiz, El Año Político, nacionalismo español, nacionalismo catalán, nacionalismo vasco.

\begin{abstract}
This article is an approximation to the trajectory of Fernando Soldevilla Ruiz (1854-1931) and to his españolista speech, that is to say, Spanish nationalist. He was a relatively prolific writer and respected journalist, with a long trajectory in newspapers of the relevance of El Imparcial or La Correspondencia de España. From humble origins was a prominent member of Spanish liberalism. He served as a civil governor and twice elected him deputy. In 1913, at the age of fifty-nine, he was appointed head of the Mercantile and Insurance Inspection, and held him until he retired in 1929 . He was characterized by being a staunch defender of a politically centralized Spain and culturally uniformized. He was one of the main critics of catalanismo and Basque nationalism, which he identified as bizcaitarras, especially from El Año político, political yearbook published in Spain, in the first decades of the twentieth century.
\end{abstract}

Keywords: Fernando Soldevilla Ruiz, El Año Político, Spanish nationalism, Catalan nationalism, Basque nationalism. 
El presente artículo se centra en el estudio del periodista, escritor, político liberal y españolista, Fernando Soldevilla Ruiz (1854-1931). La biografía es una vía útil para las investigaciones históricas. ${ }^{1}$ De hecho, su trayectoria vital tiene paralelismos con la de algunos partidarios de los nacionalismos subestatales que tanto combatió a lo largo de su vida. Soldevilla es un claro ejemplo de ese tipo de político e intelectual tan común en España, que desde sus orígenes rurales migraban hacia la capital con el objetivo de triunfar como hombre de letras y en la política. ${ }^{2}$ No obstante, a pesar de lograrlo, sus ingresos se fundamentaron en su labor como periodista, así como en la administración pública.

Entre finales del siglo XIX y principios del XX, los nacionalismos subestatales emergieron en gran parte de Europa y tuvieron un rol relevante en la construcción de identidades nacionales o regionales en el marco del surgimiento de movimientos, partidos, sindicatos, asociaciones culturales u organizaciones partidarias del secesionismo o del estado compuesto. ${ }^{3}$ Estos movimientos nacionalistas y/o regionalistas estuvieron impulsados a partir de criterios cívicos, históricos, étnicos y/o culturales, los cuales chocaban de forma casi inevitable con las identidades nacionales que defendían la centralización político-administrativa y la uniformización cultural. ${ }^{4}$

España, en este sentido, no fue ajena a esta dinámica de confrontaciones nacionalistas y regionalistas intraestatales. Ciertamente, a raíz de la crisis de 1898 , la retórica nacionalista se convirtió en una línea maestra de las fórmulas regeneracionistas. De un lado, la que representaban los dos principales movimientos nacionalistas subestatales españoles: el catalanismo, entendido como el movimiento socio político cultural que impulsaba el reconocimiento de la cultura, la lengua y el autogobierno de Cataluña, ${ }^{5}$ y el bizcaitarraismo identificado con el proyecto nacionalista impulsado por Sabino Arana. Éste editó Bizkaitarra un periódico nacionalista vasco entre 1893 y 1895 . Posteriormente, fue reeditado por los nacio-

1 Ruiz, 2014,pp. 19-46.

2 Ucelay-Da Cal, 1997.

3 Augusteijn y Storm, 2012. Núñez, 2010. Confino, 1997. Jenkins y Sofos, 1996. Coakley, 1992. Amersfoort y Knippenberg, 1991.

${ }^{4}$ Hobsbawm, 1990. Gellner, 1983. Hroc, 1998. Smith, 1988 y 2000. Anderson, 1991. Billig, 1995. Calhoun, 2007.

5 Trias, 1975. Riquer, 2001. Termes y Colomines, 2003. Pich, 2004. Gabriel, 2007. Durán, 2009. Navarra, 2012. 
nalistas vascos y su cabecera significa literalmente vizcaíno o de Vizcaya. Del otro, la elaborada por nacionalistas españoles, como el españolismo defendido por Fernando Soldevilla Ruiz, cuando aseguraba que habría hecho: «alarde, no jactancioso, de mi españolismo puro y sin tacha», cuando visitó la redacción de La Veu de Catalunya, en diciembre de $1898 .{ }^{6}$ Utilizamos el concepto españolismo para identificar el nacionalismo español de los dos grandes partidos dinásticos de la Restauración. ${ }^{7}$

Soldevilla militaba en el liberalismo que defendía la unidad nacional frente a lo que consideraban como el desafio de los nacionalismos subestatales. ${ }^{8}$ El españolismo de Soldevilla era parecido al defendido por el dirigente liberal Antonio Royo Villanova, ${ }^{9}$ y que era sumido por la mayor parte del liberalismo español.

\section{«Nunca injurié a nadie ni me valí de la influencia de la pluma para pedir nada». La trayectoria biográfica de Soldevilla}

Nació en 1854 en la población toledana de Escalona de Alberche, tenía unos orígenes humildes. Su padre era jornalero y él tuvo que trabajar para costearse los estudios. Explicaba que debía su carácter enérgico y honrado a su madre, ya que ésta le decía que le perdonaría cualquier falta, excepto si robaba o mentía. En su población natal recibió una instrucción rudimentaria y, muy joven, se trasladó a Madrid. ${ }^{10}$

En la capital española, ejerció de pasante en un colegio de la calle del Reloj, en el que ejerció de profesor, sin tener el título de magisterio. Posiblemente, pensó que podría escalar socialmente a través del periodismo. Publicó sus primeros artículos cuando tenía decisiete años, en 1871, en pleno Sexenio Democrático. Su actividad periodística le permitió mejorar su situación material, pero las «felicidades de los periodistas nos duran poco», ya que sufrió los rigores de la censura de los primeros años de la Restauración. Denunciaron un artículo que había publicado en $L a$

\footnotetext{
${ }^{6}$ Soldevilla, 22 de octubre de 1899, p. 1. Para más información sobre el proyecto y discurso nacionalista del liberalismo fusionista véase Moreno, 2002, pp.169-195.

7 Moreno, 2013 y Dardé, 2013, pp. 582-604. Sobre el nacionalismo español véase Álvarez, 2001.

${ }^{8}$ Moreno, 201, pp. 589-595.

9 Pich, Contreras y Pastrana, 2015, pp. 609-640.

${ }^{10}$ Lepina, 1929, p. 3. Ossorio, 1903, p. 435.
} 
Linterna. El editor lo delató, entendió que era muy probable que le encarcelasen y optó per emigrar a Francia. Llegó a París, donde trabajó entusiásticamente en diversas editoriales, con lo que progresó en la capital francesa. ${ }^{11}$

Explicaba que «aunque chiquito, era un guapo muchacho». Se recordaba como un joven gallardo, calavera y españolista, hasta el punto que se peleó con un francés, cuando éste dijo «varias tonterias respecto a España». Volvió del exilio en 1885, después de la muerte de Alfonso XII. Al regresar a Madrid empezó a trabajar en el diario El Día, entre 1885 y 1888. No obstante, se consagró como periodista en El Imparcial del que fue redactor entre 1888 y 1893. Posteriormente, pasó a formar parte de la redacción de La Correspondencia de España. También fue corresponsal de La Vanguardia de Barcelona, de La Voz de Guipúzcoa de San Sebastián, de La Voz de Galicia de La Coruña, y de la agencia de noticias Fourier de París. En sus últimos años colaboró en La Voz y en La Esfera..$^{12}$

Compaginaba su actividad periodística con la militancia en el Partido Liberal y, posiblemente, con su vinculación a la masonería. Fue amigo del republicano moderado y posibilista Emilio Castelar (1832-1899), que le llamaba cariñosamente «Soldevillita», mientras que para el demócrata Cristino Martos (1830-1893) era «Saldevilleja». Acompañó al lider liberal Práxedes Mateo Sagasta (1825-1903), en la mayor parte de sus viajes políticos. No obstante, su principal apoyo político era el del matemático, gran maestre de la masoneria y dirigente liberal Manuel Becerra Bermúdez (1820-1896), que «me quería como un hijo». El conservador Eduardo Dato (1856-1921) y el liberal Manuel García Prieto, marqués de Alhucemas, le honraron con la «mejor amistad». También tuvo diversas audiencias con Alfonso XIII. ${ }^{13}$ Su lema como periodista era la: «discreta indiscreción y la seriedad. Además nunca injurié a nadie ni me valí de la influencia de la pluma para pedir nada». ${ }^{14}$ Lo cierto es que supo tejer una

11 Lepina, 1929, p. 3. Serrano, 2000, pp. 11-23.

12 S.A., 7 de abril de 1931, p. 33. S.A., 6 de abril de 1931. S.A., 6 de abril de 1931. S.A., 7 de abril de 1931. S.A., 7 de abril de 1931. S.A., 7 de abril de 1931, p. 3. S.A., p. 3. S.A., 7 de abril de 1931, p. 8.

13 S.A., 30 de marzo de 1924, 29 de mayo de 1927 y 16 de junio de 1928, pp. 16, 24 y 21 . Sobre los círculos liberales en los que se sumergió Soldevilla, especialmente sagastinos: Milán, 2001, y 2000, pp. 93-122. Véase también Sáez, 2003.

14 Lepina, 1929, p. 3. 
notable red de amistades e influencias que no solo le ayudaron en su carrera periodística, sino también en la política y en su proyección profesional en la administración del Estado.

El Partido Liberal lo nombró gobernador civil de Girona, en 1897, de Segovia, en 1898, de La Coruña, en 1901 y de Granada, en 1902. Fue diputado a Cortes, entre 1894 y 1895, y en la legislatura de 1910 a 1914. En su primera etapa como parlamentario criticó las cesantías de los empleados públicos. Posiblemente, sabía de lo que hablaba, ya que era víctima de ellas por su adscripción a una de las facciones dinásticas. ${ }^{15}$ En el Congreso y en la sección de Historia del Ateneo de Madrid dio muestras de su elocuencia. ${ }^{16}$

En 1912, sus compañeros periodistas lo describían, como un leal demócrata que «ha tenido la cachaza de ver cómo su enmarañada cabellera encanecía sin tener un desmayo, sin padecer una vacilación; don Fernando, este consecuente liberal que publica todos los años un libro muy liberalón», en referencia a $E l$ Año Político. Sería el «último romántico de nuestra política». Lo presentaban con un poco de sorna, como un hombre «ingenuo, amable, archisimpático, risueño que florece aún como una siempreviva en el yermo un poco desengañado que es hoy el Congreso; don Fernando, el bueno, el angelical, el que piensa, tan reciamente como Posada Herrera y hasta como Ruiz Zorrilla, no puede ver, no puede soportar, odia, detesta» todos los proyectos políticos que cuestionasen el sistema político centralista y la uniformización cultural. Era el representante: «futuro de aquella generación política que supo llevarnos al desastre, pero que nos llevó tan risueña, tan entusiasta, ¡tan patrióticamente!». ${ }^{17}$

Durante muchos años formó parte del Consejo Superior de Protección a la Infancia. Era socio de mérito de la Asociación de la Prensa de la que fue uno de sus impulsores en 1895. Así como, socio honorario del Círculo de Bellas Artes. Poseía la cruz de Isabel la Católica, la del Mérito Naval de segunda clase, la Nichan Iftikhar de Túnez, la del sitio de Zaragoza y la de la Coronación de S. M. el Rey. ${ }^{18}$

15 S.A., 28 de junio de 1895 , p. 5. Para el período canalejista del liberalismo véase Forner, 1993.

${ }^{16}$ Lepina, 1929, p. 3. S.A., 7 de abril de 1931, p. 5. S.A., 7 de abril de 1931 , p. 3.

17 S. A., 29 de junio de 1912, p. 9.

18 S.A., 7 de abril de 1931, p. 33. 
Era autor de una novela, El cura loco, de diversos trabajos históricos de los que los más relevantes eran: Tres revoluciones y Los hombres de la libertad. Estrenó el drama Juez y reo y escribió el texto de la zarzuela, con música de Gonzalo Cantó (1859-1931), El Cristo de la Vega, entre otros trabajos literarios. ${ }^{19}$

En 1905, era jefe de la sección de beneficencia del ministerio de Gobernación, y oficial mayor del mismo ministerio al cabo de un año. De 1913 hasta 1929, cuando lo jubilaron con casi setenta y cinco años, ejerció la jefatura de la Inspección Mercantil y de Seguros en el Ministerio de Trabajo. Posiblemente, su carrera funcionarial era un premio a su trayectoria política. ${ }^{20}$ Sus admiradores aseguraban que pudo «haber llegado, gracias a sus relaciones a los más altos puestos de la Administración». Obviaban que éstas le permitieron ser designado Gobernador Civil en cuatro capitales de provincia, diputado en dos legislaturas y jefe de un relevante negociado durante quince años, sin tener ningún conocimiento acreditado sobre la materia. A los setenta y cuatro años, «con muchos ex y con muchas cruces, que jamás se ha colgado, se sigue ganando la vida; pero muy alegre, muy honrado y muy satisfecho de seguir siendo periodista». ${ }^{21}$

\section{«Esta imparcialidad será absoluta en tal grado que, para conseguirla, omitiré toda clase de comentarios». El Añ̃o Político}

Era uno de los dosieres políticos de noticias de prensa con más circulación. Así en la portada del de 1897 aseguraban que se había agotado las ediciones de 1895 y de 1896. A partir del de 1897, Soldevilla añadió un informe del Secretario de la Real Academia de Ciencias Morales y Políticas que recomendaba la compra de su anuario. En 1903, anunció que ante los reiterados informes favorables entre 1896 y 1902, el Ministerio de Instrucción Pública se suscribió a la obra y ésta llegaba a gran parte de las Bibliotecas Públicas de toda España. ${ }^{22}$

${ }^{19}$ Lepina, 1929, p. 3. Sus obras más remarcables son: Soldevilla, 1879, 1881, 1883, 1884, 1885, 1886, 1887a, 1887b, 1900a, 1900b, 1910, 1917a, 1917b, 1927 y 1930.

${ }^{20}$ El contexto de construcción corporativa de la función pública en los años de la Restauración en Villacorta, 1989.

21 Lepina, 1929, p. 3.

22 Fernando Soldevilla, El Año político (1903) Año IX, Madrid, Imprenta de Ricardo Rojas, 1904, (en adelante, EAP), p. VIII. 
En 1929, Soldevilla era considerado uno de los veteranos del periodismo español y cuando repasaban su trayectoria aseguraban que su obra más extensa y considerable era El Año Político, «colección de inestimable valor y que en el porvenir será un valioso documento, del que lleva publicados treinta y tres volúmenes. Esta verdadera historia vivida de todos los sucesos sociales y políticos de España, con mención de los más salientes del extranjero, supone por si sola un esfuerzo enorme». ${ }^{23}$

Soldevilla aseguraba que la única condición para elaborar un dosier político sería la imparcialidad, y ésta «será absoluta en tal grado que, para conseguirla, omitiré toda clase de comentarios, limitándome sólo á consignar los hechos tal como á mi conocimiento llegaron». ${ }^{24}$ Sin embargo, la simple selección de las noticias ya muestra el pensamiento del autor. Sus dosieres reflejan su ideología españolista y crítica con cualquier opción política que apostase por la descentralización del estado. Así pues, cuando en 1899 el gobernador civil de Barcelona, el navarro Eduardo Sanz Escartín, ${ }^{25}$ dijo que entendía que Cataluña habría llegado a la mayoría de edad y que el Gobierno impulsaría la descentralización administrativa. Soldevilla aseguró que «se comprendió enseguida que esto había de contribuir por modo extraordinario á envalentonar el catalanismo, ya bastante exacerbado, de lo cual había dado tristes pruebas». ${ }^{26}$

Ante la consolidación del catalanismo político afirmaba que: «mientras fueron precisos la sangre y el dinero de toda España para dominar las colonias (de donde sólo unas cuantas provincias sacaban producto), el regionalismo se mantuvo en el terreno de la literatura; pero en cuanto se vio que la guerra acabaría por la ruina de España, se convirtió en un movimiento económico y político. No se puede negar que esto sea humano, pero no es justo». ${ }^{27}$ Así pues, en 1899, resulta lógico que se opusiese a la coalición política entre el general Camilo Polavieja, el conservador regeneracionista Francisco Silvela y una plataforma de polaviejistas catalanes partidarios de la descentralización española y de la obtención del concierto económico. ${ }^{28}$

23 Lepina, 1929, p. 3.

${ }^{24}$ EAP, 1896, pp. 4-8.

25 Monereo, 2010. Campo, 2011, pp. 177-205. Risques, 2012.

26 EAP, 1900, p. 281.

27 Soldevilla, 1900b, pp. 62-193. Era un compendio de los artículos publicados en El Imparcial, en 1899. Veáse también Colomines, 1991, p. 265.

${ }_{28}$ Riquer, 1987, p.78, y 1999, pp.46-51. 


\section{«Le llevaron á fomentar el regionalismo de una región á la cual él no pertenecía». El anticatalanismo}

En las elecciones generales de mayo de 1901, se concretó la victoria simbólica de la candidatura de los cuatro presidentes, aunque ésta se circunscribió a la demarcación de la ciudad de Barcelona y obtuvieron únicamente cuatro diputados regionalistas encabezados por el presidente de la Sociedad de Amigos del País de Barcelona, el doctor Bartomeu Robert. ${ }^{29}$ No obstante, posibilitó que los catalanistas comenzasen a desarrollar la idea que su victoria electoral había sido el punto de partida que acabaría con la ficción que caracterizaba a las elecciones en el período de la Restauración. Certificando la consolidación del catalanismo en la vida política española como abanderado de la reforma y de la regeneración del estado. ${ }^{30}$

En estas circunstancias, los partidarios del centralismo político hicieron creer a buena parte de la opinión pública española que el catalanismo era potencialmente peligroso, pero confiaban en qué no cuajaría. Sagasta se tomó un poco a broma la elección de los diputados regionalistas, mientras que otros pensaban que sus reivindicaciones se podrían reducir a un debate académico. Sin embargo, la masa informe de los catalanistas habría quedado encuadrada y disciplinada con un jefe, el doctor Robert; un programa, las Bases de Manresa; una organización, la Lliga Regionalista, y un espíritu de patria, que identificaban con Cataluña. Existía una nueva formación política que pretendía cambiar el sistema político español e impulsar un proyecto regeneracionista y modernizador. Inicialmente, los defensores del centralismo le aplicaron una «conspiración de silencio» para ver si todo quedaba muerto a base de no hablar de ello. ${ }^{31}$

No todos se callaron, ya que los españolistas viscerales consideraban que los catalanistas odiaban a Castilla, porque enarbolaban la bandera catalana. Afirmaban que el proyecto regionalista era contrario a la unidad de España. Además, los acusaban de ser «exaltados, separatistas furibundos y anarquistas». En El Año Político reprodujo artículos de El Imparcial que fustigaban al catalanismo, ya que sus propuestas serían una infamia que ofendía y deprimía al resto de los españoles. El gobierno acusó a los acaudalados catalanistas de sembrar la semilla separatista.

\footnotetext{
29 Izquierdo, 2002a.

30 Izquierdo, 2002b.

31 Garriga, [1987], pp. 139-140.
} 
Prácticamente toda la prensa que se publicaba en la capital española los criticó. Lo paradójico era que los regionalistas, de los que una buena parte procedía del conservadurismo dinástico, no dudaron en reafirmar que su patriotismo catalán era compatible con su propia españolidad, pero para los centralistas el regionalismo particularista era contrario a la «unidad de la patria». ${ }^{32}$

En todo caso, las cabeceras de prensa más españolistas no dudaron en acusarlos de ser separatistas, de decir horrores de España, y los equipararon a una enfermedad. Unas críticas que impulsaban fundamentalmente los liberales. Buena parte de los conservadores no veía con tan malos ojos la propuesta regionalista, especialmente el sector liderado por el político mallorquín Antonio Maura. No obstante, el también conservador Romero Robledo cuestionaba que se pudiese utilizar la lengua catalana en público y apoyó al radical Lerroux en sus críticas en contra de los catalanistas. En este período, el líder conservador Francisco Silvela aseguraba que el proyecto de los diputados de la Lliga no era nuevo, ya que se trataría de un federalismo monárquico. No estaba de acuerdo con lo que proponían, porque entendía que no sería constitucional, pero les reconocía el derecho de discusión, aunque «nada de concierto económico, ni de Diputación única». 33

Los centralistas afirmaban que el catalanismo era una dolencia nacional o, en palabras del liberal catalán, José Roig y Berguedá, una masturbación cerebral, y aseguraban que realmente eran nacionalistas. En cambio, el doctor Robert argumentó en el Congreso que no eran contrarios a la unidad española, sino a su uniformidad, defendió el programa formulado en las Bases de Manresa, y aseguró que sus propuestas beneficiarían a España. Este discurso inició un prolongado debate parlamentario. Las réplicas fueron durísimas incluyendo una propuesta de ley en contra de los «delitos contra la integridad de la patria». Soldevilla consideraba a los anticatalanistas como españolistas, y no tenía reparos en afirmar que en Cataluña luchaban los catalanistas con los castellanos. ${ }^{34}$

En abril de 1902 falleció el doctor Bartomeu Robert. Éste había nacido en Tampico, en 1842, ya que su padre era un médico catalán que

${ }^{32}$ EAP, 1902, pp. 89, 107-108, 110-114, 134, 164-165, 189-191, 202, 217. Riquer, 2001, pp.217-236.

${ }_{33}$ EAP, 1902, pp. 219-222, 226-227, 239-240, 248-249, 268, 316, 318, 324-325, 328-330.

${ }^{34}$ Ibidem, pp. 331, 336-351. 
ejercía en aquella población mejicana. Volvieron a Cataluña cuando era un niño y, según Soldevilla, «fue, realmente, hombre de mérito, pero su afán de notoriedad y su amor á la populachería, le llevaron á fomentar el regionalismo de una región á la cual él no pertenecía, y á incurrir en exageraciones rayanas en el separatismo, por lo cual, hablando sin hipocresía ni temores, puede decirse de él que, si como hombre de entendimiento y de ciencia pudo sentirse su muerte, nada perdió con ello la unidad de la Patria española [la cursiva es de Soldevilla]». ${ }^{35}$

\section{«Un imbécil bizcaitarra». El nacionalismo vasco}

Las propuestas descentralizadoras no fueron patrimonio de los catalanistas, sino que estas se hicieron extensibles a diferentes regiones de España. En este sentido, el bizcaitarrismo puede ser visto como una expresión de las clases medias rurales vizcaínas contra el régimen de 1876. El proyecto político de Sabino Arana, procedente del carlismo, tenía un fuerte contenido antiliberal. ${ }^{36}$ De hecho, la respuesta desde el españolismo podría ser interpretada como tan esencialista como la del sabinismo.

En junio de 1899, Soldevilla reprodujo el discurso del senador republicano José Fernando González (1836-1915) en que se mostraba preocupado por la «vida del Estado nacional», entre otros motivos por el hecho que: «En las Vascongadas, singularmente Vizcaya, se está haciendo una propaganda separatista de cuidado. En cuatro ó cinco días se ha creado un centro separatista con lo principal de Bilbao. Por eso creo que son un peligro para la patria, para la unidad del Estado nacional». Coincidía con el entonces ministro Manuel Duran i Bas (1823-1907), que «hemos vivido en una uniformidad infecunda», pero se preguntaba: «ies que vamos á la federación dentro de la monarquía?». Sabiendo que la respuesta era negativa. ${ }^{37}$

Soldevilla identificaba como «separatistas vizcaínos ó bizkaitarras» al grupo encabezado por Sabino Arana, «de quien poco tiempo antes hacían mofa las gentes de buen humor de la capital de Vizcaya». Aseguraba

35 EAP, 1903,pp. 139-140, 417, 418-419.

36 Arana, 1980 y 1995. Muy críticos con el proyecto político doctrinal de Arana: Corcuera, 2001. Antxustegi, 2007. Elorza, 2005. También crítico con Arana, pero con otra óptica Ezkerra, 2003. Una perspectiva diferente en: Ugalde, 1984. Una síntesis en Granja, 2015.

37 EAP, 1900, pp. 211-212. 
que había sido elegido diputado provincial por «causas secundarias», y explicó en El Año Político que se dirigió al presidente de la Diputación, «Aresti, censurándolo por los obsequios que se hicieron á la infanta doña Eulalia». El salón de sesiones estaba ocupado por nacionalistas vascos que gritaron: «iviva Vizcaya! ¡viva el diputado nacionalista! ¡abajo los diputados extranjeros! ¡abajo los chavarristas! ¡abajo el dinero!...».38

En una nueva muestra de su imparcialidad, Soldevilla aseguraba que: «la opinión unánime censura la actitud de esos cuatro locos deseosos de notoriedad, que no otra cosa son los bizkaitarras». Copió una noticia en El Año Político en qué explicaba que «tanto alborotan esos nacionalistas, de tal manera escandalizan esos locos, que si cuanto antes no se les llama al orden y se les pone una camisa de fuerza, van á ser causa que el resto del país forme de la leal y trabajadora Vizcaya un juicio nada lisonjero». Añadía, que según gente bien informada Sabino Arana sería un «mentecato, y los que lo apoyaban lo hacían, no porque participasen de sus ideas, sino en odio y por combatir al Sr. Chavarri, rico industrial de Bilbao, que con su dinero y su caciquismo había desmoralizado la provincia». ${ }^{39}$

El 12 de septiembre de 1899, el Gobierno suspendió las garantías constitucionales en Vizcaya. El jefe del Gobierno, el conservador Francisco Silvela, intentó justificar esta medida explicando que la decisión pretendía extirpar «todo germen separatista en aquella región del Norte de España, donde recientemente - dijo- se han realizado actos y manifestaciones contrarios á la unidad nacional. Más que la medida se censuró aún la explicación, pues todo el mundo consideró como una verdadera imprudencia por parte del Gobierno el empeño de explicar aquella medida extraordinaria por la necesidad de tener á raya á los separatistas bilbaínos». El gobernador civil de Bilbao, con el apoyo explícito del Gobierno, clausuró el Centro Vasco y el Orfeón Euskeria de Bilbao. Así como, las asociaciones Batroki-Benekatarra de Bermeo, y Euskalduna de Baracaldo. También suspendió la publicación de El Correo Vasco, porque «venía haciendo una furiosa campaña separatista»..$^{40}$ En julio de 1900 finalizó la suspensión de las garantías constitucionales. ${ }^{41}$

Durante el viaje de Alfonso XIII a Bilbao, sólo hubo un incidente menor. Sin embargo, Soldevilla aprovechó la noticia para asegurar que la

\footnotetext{
38 Ibidem, pp. 282-283.

39 Ibidem.

40 Ibidem, pp. 311-312, 314, 370 y 376.

41 EAP, 1901, p. 240.
} 
nota desagradable de la visita fue debida a los bizcaitarras: «esos malos españoles, que por excesiva tolerancia de los Gobiernos tienen círculos y exponen sus ideas contrarias á la unidad de la patria, y que, á ejemplo de los catalanistas, no perdonan medio para demostrar sus viles sentimientos de desamor á España». ${ }^{42}$ En cambio, consideraba ejemplar el discurso que el catedrático Miguel de Unamuno pronunció en los juegos florales de Bilbao del que aseguraba que rebosaba «párrafos de sabiduría y de patriotismo», especialmente cuando afirmó que nada podría impedir la «próxima muerte» del «dialecto vascuence». Añadía que los incidentes causados por los nacionalistas vascos ante el discurso de Unamuno serían un ejemplo de la «intemperancia de los bizkaitarras, locos ó malvados, que abominan de la patria española». Para los españolistas negarse a aceptar la desaparición de la lengua vasca sería una muestra de separatismo, aunque «afortundamente hechas por una insignificante minoría, y con la protesta de todas las personas honradas». ${ }^{43}$

Otro ejemplo de su imparcialidad objetiva la encontramos cuando reprodujo la noticia publicada por El Noticiero Bilbaíno, en la que se informaba que Sabino Arana, jefe de los nacionalistas vizcaínos, había enviado un telegrama al presidente norteamericano felicitándolo por haber proclamado la independencia cubana. Soldevilla tituló la noticia: «un imbécil bizcaitarra», y añadía que en el telegrama es de «presumir que en su texto contenga expresiones depresivas para la patria, dada la intervención de las autoridades judiciales en el asunto. Fue preso este imbécil». ${ }^{44}$

En noviembre de 1903, ante la muerte de Sabino Arana, Soldevilla explicaba que había sido el «fundador, Jefe y propagandista del bizcaitarrismo ó separatismo, más ó menos vergonzante, que tanto dio que decir por sus insultos á la Patria española. El Sr. Arana estuvo preso á consecuencia de un telegrama que dirigió al Presidente de los Estados Unidos, cuando se concedió la independencia á la República cubana, telegrama ofensivo para España. Si como particular pudo ser sentida su muerte, pues los que le trataban decían que era hombre honrado, nada perdió con ella la Patria española, á la cual befó y menospreció». ${ }^{45}$

Soldevilla defendía un nacionalismo español explícito, excluyente y separador. Desde su perspectiva los nacionalismos subestatales serían an-

\footnotetext{
42 Ibidem, pp. 268-269.

43 EAP, 1902, pp. 226-227 y 235-237.

44 EAP, 1903, pp. 233-234.

45 Ibidem, pp. 448-449.
} 
tiespañoles y se estaban consolidando, a partir de las «verdaderas osadías de los catalanistas», pero el supuesto «mal ejemplo catalán», también se extendía a Vizcaya. En 1906, en Valencia argumentaban que: «FRENTE Á LA SOLIDARIDAD INDUSTRIAL DE CATALUÑA Y VIZCAYA OPONEMOS LA SOLIDARIDAD AGRíCOLA DE LEVANTE». ${ }^{46}$ En febrero de 1907, en Bilbao, a raíz de la representación teatral de El Intruso de Vicente Blasco Ibáñez habrían llevado a cabo una "verdadera manifestación separatista», ${ }^{47}$ en la que un carlista gritó viva España y «recibió en pleno rostro los salivazos de los separatistas». ${ }^{48}$

En agosto de 1908, Alfonso XIII visitó la sede de la compañía naviera «Euskalduna» presidida por el dirigente bizcaitarra Ramón de la Sota (1857-1936). ${ }^{49}$ No obstante, los talleres «estaban engalanados con más banderas nacionales que vizcaínas». Los centralistas pensaban que Euskalduna «órgano de los bizkaitarras, publicaría declaraciones dinásticas; pero no lo hizo; al contrario», ya que afirmaron que «perdura en los vizcaínos el sentimiento de amor á sus instituciones seculares». ${ }^{50}$

\section{«Atentan contra España». Los sucesos de Barcelona, Solidaritat Catalana y la Mancomunitat}

En este contexto, ya habían hecho su aparición en Cataluña unas nuevas generaciones de nacionalistas que tanto en su discurso como en sus objetivos políticos eran más radicales que la Lliga Regionalista. Utilizaban la retórica independentista, aunque su supuesto secesionismo encubriría un proyecto político mayoritariamente federal. Al igual que los jóvenes radicales vascos, tendieron a ocupar simbólicamente las calles de Barcelona, aunque de forma muy minoritaria, con acciones provocadoras propias de jóvenes adolescentes, destacando la quema de banderas españolas y la celebración del 11 de septiembre de $1714 .{ }^{51}$ Acciones que ayudaron a consolidar una relectura de la tradición catalanista con un lenguaje cada vez más propio de un nacionalismo que aspira a crear un estado-nación.

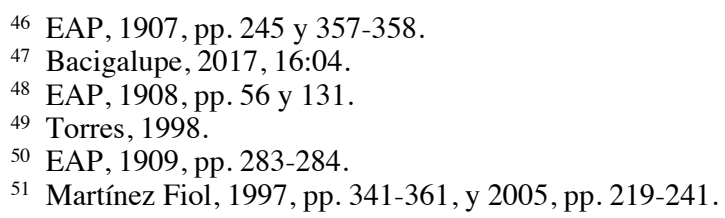


Los centralistas se enfrentaron a las reivindicaciones emergentes de autogobierno que contaban con el apoyo de las cada vez más numerosas clases medias partidarias del catalanismo. 52

Soldevilla describía imparcialmente al catalanismo como cobarde y vil separatismo, cuando informó del acto que organizó El Progrés Autonomista para celebrar el tercer aniversario de la independencia cubana. Desde su perspectiva, los catalanistas serían soberbios y malos españoles, ya que: «después de haber contribuido más que nadie á la pérdida de nuestras colonias, por la protección exagerada concedida á sus productos, por lo cual se enriquecieron fabulosamente, en pocos años, gentes sin instrucción ni méritos; algunos de los cuales (por confesión propia lo sabemos) tiraban de un carretón para vivir é hicieron enormes fortunas; estos catalanistas no perdonaban ocasión de zaherir á España, después de haber contribuido á su ruina». Para los españolistas la mera existencia del catalanismo era un atrevimiento, ya que: «la propaganda y las manifestaciones todas del catalanismo, tienen siempre un carácter de agresión y de ofensa tal á todo lo genuinamente español, que irrita aun á los menos entusiastas del sentimiento patrio». ${ }^{53}$

El choque entre los defensores del centralismo del que hacían bandera los militares acuartelados en Cataluña, con el apoyo explícito y vehemente de Soldevilla, y los catalanistas se concretó en los hechos del $\mathrm{Cu}$ Cut! de 1905. El relato publicado por El Año Político estuvo mediatizado por el españolismo de su compilador y su única imparcialidad se limitó a la utilización de los artículos publicados por El Imparcial. Un diario que se caracterizaba por su anticatalanismo y por ser uno de los principales portavoces del españolismo entendido como la defensa de la centralización político administrativa y del uniformismo cultural.

Inició el relato de los sucesos que culminaron con el asalto de las redacciones del Cu-Cut! y de La Veu de Catalunya, con el banquete de la Victoria que tuvo lugar, en noviembre de 1905, en el frontón Condal de la capital catalana. Desde su perspectiva, «lo sucedido era inevitable, fatal, dada la procacidad y la grosería de los catalanistas, y la pasividad y la tolerancia censurable que usaban las Autoridades ante tales procedimientos». Explicó que los catalanistas publicaban en Barcelona un semanario satírico llamado $\mathrm{Cu}$-Cut, que defendería el «más rabioso catalanismo (di-

52 Hernández y Pinyol, 2000; Santolaria, 2005; Casals, 2016 y la Capitanía General de Cataluña como un poder autónomo al civil en Calvo, 1974.

${ }^{53}$ EAP, 1906, pp. 163-164, 357, 361-362, 380-381. 
gamos francamente separatismo), dirigía agravios continuos á España y á los españoles é insertaba frecuentemente trabajos gráficos y literarios contra el Ejército español. Sus osadías habían llegado á lo que es por la ley indiscutible. Tales antecedentes explican lo acontecido». Calificaba a la revista satírica vinculada a la Lliga de «libelo» que había publicado unas caricaturas que fueron denunciadas y la revista requisada, porque serían «ofensivas para nuestro Ejército. Aunque recogida la edición del periódico, no dejarían de circular algunos ejemplares, de manera que tuvieron conocimiento de ello algunos Oficiales de la guarnición de Barcelona. Un grupo de Oficiales fue á la redacción de $\mathrm{Cu}$-Cut é impuso el castigo correspondiente á las ofensas, cosa que aparte de lo que pueda relacionarse con la disciplina, le pareció muy bien á todo el mundo, pues ya no podía sufrir tales insultos, sin que Gobernadores ni Jueces fuesen á las manos [sic.] [con] los criminales autores de tantas infamias. Porque hay que repetir una vez más que los insultos iban contra la Patria y contra el Ejército que la representa». ${ }^{54}$

La mayor parte de la oficialidad española reclamó una ley que pusiese bajo la jurisdicción de los tribunales militares los presuntos delitos contra el Ejército y la patria. El Gobierno, en manos de los liberales, aprobó la ley de jurisdicciones. Ésta limitaba la libertad de expresión e indignó a la mayor parte de la sociedad catalana, hasta el punto que decidieron constituir un movimiento político al que llamaron Solidaritat Catalana del que formaban parte todas las formaciones políticas catalanas, excepto los republicanos radicales de Lerroux y los anarquistas. Los nacionalistas españoles afirmaban que los catalanistas eran aquellos «señores, que en cuanto alguien con autoridad se les encara, protestan de su amor á España, no cesaban de ofender á la integridad de la Patria, á España y al Ejército», y aseguraban que habrían constituido la «solidaridad carlo-republicana-catalanista», mientras Lerroux los acusaba de ser hipócritas por ocultar su separatismo..$^{55}$

En 1907, las candidaturas de Solidaritat Catalana obtuvieron 42 escaños de los 44 posibles de todas las circunscripciones electorales catalanas. El gobierno pasó a manos de los conservadores liderados por Maura y su principal iniciativa legislativa era el proyecto de reforma de las adminis-

${ }^{54}$ Ibidem, pp. 460-464.

55 Garriga, [1987], pp. 155-159. EAP, 1906, pp. 473-493, у 1907, pp. 68-74, 79-82, 85-101, 103-109, 117-123, 132, 137-141, 153-160, 162-168, 173-176, 225-230, 257-265, 358-359, 434-435 y 499-500. Rubí y Espinet, 2008. 
traciones locales y provinciales, en el que se establecía la posibilidad de constituir mancomunidades de Diputaciones provinciales. Los centralistas pensaban que las mancomunidades posibilitarían el autogobierno de Cataluña, aunque se trataba únicamente de una descentralización administrativa. En este período, las críticas al proyecto de ley que posibilitaría las mancomunidades provenían de todas las tendencias liberales. Éstos se encontraban en la oposición, y hasta los demócratas encabezados por Canalejas consideraban que si con las mancomunidades Cataluña tuviese un sistema de autogobierno distinto al resto de los españoles, «á eso no puede irse», ya que se trataría de una normativa inconstitucional. ${ }^{56}$

La revolución de julio de 1909 implicó la disolución de Solidaritat Catalana y que el gobierno pasase a manos de los liberales, ${ }^{57}$ Canalejas quiso encontrar una solución para el problema catalán, a pesar de la oposición que generaba entre sus partidarios, hasta el punto que dos diputados liberales, Niceto Alcalá Zamora y el propio Fernando Soldevilla, intervinieron en el debate para oponerse a la aprobación de las Mancomunidades.

A los ojos de las diferentes sensibilidades del nacionalismo español, pero especialmente del liberalismo, el problema que generaba el proyecto de Mancomunidades era el de su carácter de institución supraprovincial. Canalejas no dio libertad de voto a los diputados liberales que apoyaban a su Gobierno. No obstante, cuatro días antes del inicio de la discusión parlamentaria, Soldevilla le envió una carta, en la que le solicitaba poder expresarse con total libertad para oponerse al proyecto de Mancomunidades. Canalejas le respondió que si no se aprobaba la ley dimitiría, pero que «si alguna personalidad, por sus circunstancias especiales, no puede asistirme con su adhesión en el debate» no le expulsaría del partido. Soldevilla consideró que las circunstancias especiales le eran aplicables, porque estaba convencido que cualquier tipo de descentralización sería perjudicial para su concepción de España. ${ }^{58}$

El 28 de junio de 1912, fue el primer diputado liberal en intervenir en contra de la aprobación de la ley de Mancomunidades. En la crónica parlamentaria del $A B C$ aseguraban que cuando se le concedió la palabra había una gran emoción, ya que un diputado de la mayoría se opondría al proyecto de ley que defendía el Gobierno de su partido. Sin embargo, Sol-

\footnotetext{
56 EAP, 1908, pp. 226-228, 231 i 451.

57 Ullmann, 1972 [2009]. Romero, 1975. Pich, 2015, pp. 173-206.

58 EAP, 1908, pp. 265 i 269-280.
} 
devilla consiguió «al conjuro de su amenidad, convertir en regocijo la incertidumbre», especialmente cuando afirmó que viviría de «buen grado en esa bella región, junto al mar latino, entre aquellos campos sembrados muy bien, entre aquellas mujeres...» Afirmación que generó la hilaridad de los congresistas, por el contraste con el orador: «tan chiquito, mal afeitado, ya con su cabellera encanecida, blandiendo sus gruesos quevedos». El regionalista Josep Bertran i Musitu «ese gran amador, para no morir, salióse riendo a carcajadas». Sin embargo, Soldevilla estaba «profundamente indignado. Nosotros hemos visto pocas veces á un hombre más furioso. Todos los prejuicios del Sr. Soldevilla se han visto amenazados por esas pícaras mancomunidades que se le ocurrieron á ese demonio del Sr. Cambó. "Mi actitud - exclama el Sr. Soldevilla aniquilando á las mancomunidades - es clara. No se deben conceder. Atentan contra España"». .9

En El Año Político argumentaba que el proyecto que posibilitaría la constitución de mancomunidades sería: «peligroso para la unidad de la Patria, y favorable, no para Cataluña, ni siquiera para Barcelona, sino solamente para una reducida oligarquía que buscaba con esta bandera tan particularista, el monopolio, el acaparamiento de la influencia política y de los intereses administrativos». A diferencia de lo que habían entendido sus colegas del $A B C$ el demonio del que habría surgido la propuesta era Prat de la Riba, «padre legítimo del proyecto, pues el Sr. Cambó sólo es padre putativo». En referencia a la potencial descentralización de la educación pensaba que implicaría «la ausencia del Estado en el alma nacional». Además, desequilibraría el presupuesto, ya que si aprobaban su constitución la «mancomunidad aparecerá con dos manos, para recoger del presupuesto nacional y del presupuesto local». En síntesis, iniciar el proceso de descentralización implicaría la instauración de una nueva oligarquía y sería muy negativo para la concepción de la nación española defendida por Soldevilla. ${ }^{60}$

Los nacionalistas españoles pensaban que los catalanistas con la $a u$ dacia de cantar Els Segadors, el actual himno oficial de Cataluña, pondrían de manifiesto la «inutilidad de las reformas que se les concedieran en la ley de Mancomunidades, o se les pudiera conceder en cualquiera otras». La ley se aprobó en el Congreso, pero se tenía que discutir en el

\footnotetext{
59 S. A., 29 de junio de 1912, p. 9.

60 EAP, 1913, pp. 294-295. Medina, 1995.
} 
Senado presidido por el líder liberal y defensor del centralismo Montero Ríos. Parecía que aprobarían la ley, aunque acentuase la división entre los liberales, cuando Canalejas fue asesinado por el anarquista Manuel Pardiñas. ${ }^{61}$

A principios de enero de 1913, el romántico y desinteresado Soldevilla consiguió que le nombrasen oficial mayor de la Comisaría general de seguros, ${ }^{62}$ cuando aún no había finalizado la legislatura y ocupaba su escaño. No extrañó a nadie que nombrasen a un diputado liberal, cercano a la sesentena, conocido como periodista y escritor, pero sin tener acreditados conocimientos sobre el negociado que dirigiría. El nombramiento podría ser visto como un acto de prevaricación y de nepotismo.

El asesinato del líder liberal, parecía que también habría matado la ley de mancomunidades. Pero los catalanistas estaban movilizados, los dos grandes partidos dinásticos se encontraban en crisis. El Gobierno volvía a estar controlado por los conservadores. En estas circunstancias, el 18 de diciembre de 1913, Eduardo Dato decidió acabar con el problema de las Mancomunidades autorizándolas, a través de un Real Decreto, ante la indignación de Soldevilla, que consideraba que aquel era un día nefasto para su concepción de España. ${ }^{63}$

El 6 de abril de 1914, eligieron a Enric Prat de la Riba presidente de la Mancomunitat, al mismo tiempo que mantenía la presidencia de la Diputación de Barcelona. En su primer discurso presidencial vinculó la Mancomunitat con el autogobierno perdido con la derrota en la guerra de sucesión, aunque se trataba únicamente de una descentralización administrativa. El gobierno no le transfirió competencias y estaba mal financiada. No obstante, los catalanistas impulsaron para la posteridad la imagen de una extraordinaria labor educativa, la unificación de la normativa lingüística realizada por Pompeu Fabra, así como la construcción de infraestructuras, la mejora de las comunicaciones y de la sanidad. ${ }^{64}$

${ }^{61}$ EAP, 1912, pp. 518-523 y 1913. pp. 220-226, 265, 269-280, 294-295, 296-297, 353, 385-386, 410-411, 423-425, 432-433 y 447-457. S. A., 29 de junio de 1912, p. 9. Garriga, [1987], pp. 191-196.

62 S. A., 4 de enero de 1913, p. 12.

${ }^{63}$ EAP, 1913, pp. 472-473, 500-501 y 547, 1914, pp. 74, 187-189, 238-285, 296-297, 413-415, 424-458, 526-534.

${ }^{64}$ Ucelay-Da Cal, 1987, pp. 37-259. Balcells, Pujol y Sabater, 1996; Roig, 2014; Balcells, 2014. Colomines y Madaula, 2014, y Bassols, 2014. 
El 1 de agosto de 1917 murió Prat de la Riba. Soldevilla había sido muy crítico con el difunto presidente de la Diputación de Barcelona y de la Mancomunitat catalana, ya que había sido el: «alma del movimiento regionalista, derivado en la última época de su vida hacia el nacionalismo. Prat de la Riba fue quién lanzó la idea escueta de la nacionalidad y quien sostuvo que Cataluña, nación libre en el pasado, debía volver a serlo». Para impulsar su proyecto político doctrinal habría apelado a: «todas las formas agresivas para lo que los nacionalistas llaman Castilla, que es toda España que no es Cataluña, Aragón y Valencia». Lo consideraba un fanático anticastellano. No habría querido ser parlamentario en el Congreso de los Diputados por «no tener cargo alguno de carácter nacional español, y puso todas sus aspiraciones en ser lo que fue, todo en Cataluña, a la cual desespañolizó por todos los medios que pudo: en cátedras, empleos, teatro, religión, etc., prohibiendo que se hablase el castellano en todos los centros en que mandaban y disponían los organismos provinciales y municipales. Aceptó, por muchos ruegos, la Gran Cruz de Isabel la Católica; pero ni la llevó jamás, ni tuvo por ella el menor aprecio». Añadía que, «como en este libro no se dice más que la verdad», siempre había sido adversario irreconciliable de Prat de la Riba, aunque le reconocía una gran inteligencia, una voluntad férrea y una moralidad sin mácula. «iLástima que todas estas cualidades no las empleara en pro de la nación española!».65

Sabía que Prat no era secesionista, pero consideraba intolerable que pretendiese que España aceptase la oficialidad de la lengua y el autogobierno catalán. También reconocía que en una entrevista Prat le habría dicho que: «no somos separatistas, porque entendemos que esta solución hoy es perjudicial a Cataluña; pero no somos españolistas, porque el Estado español es incorregible, y antes que dar satisfacción a Cataluña, preferirá que todo se hunda». Soldevilla consideraba que Cataluña es: «deudora a Prat de la Riba de todos los honores, de la más profunda gratitud y de eterna recordación, y seguramente pagará su deuda, en lo cual cumplirá con el más sagrado de los deberes de los pueblos; en cuanto a España, en lo que respecta a la nacionalidad española, ésta hubiera ganado mucho con que Prat de la Riba no hubiera existido».66 252 .

${ }^{65}$ EAP, 1918, pp. 357-358. Garriga, [1987], pp. 213-234. Colomines, 1993, pp. 221${ }^{66}$ EAP, 1918, pp. 358-359. 


\section{«Separatismo, más o menos vergonzante». El bizcaitarrismo}

La crisis de los liberales en Vizcaya habría impulsado tanto a los socialistas, como al «separatismo, más o menos vergonzante, que se oculta bajo la máscara del bizcaitarrismo». En febrero de 1910, los nacionalistas vascos tuvieron una polémica con el obispo de Vitoria, José Cadena y Eleta, ya que éste se negó a «autorizar la estúpida pretensión de dichos elementos de que se les bautizara en vascuence». En marzo, defendieron la creación de escuelas vascas propuesta que Soldevilla interpretaba como un ataque al laicismo y «contra el castellano». En agosto, hubo una algarada bizcaitarra en qué gritaron vivas a «Euskaria libre y mueras á España y á Canalejas», con muchas detenciones. Soldevilla calificaba a los nacionalistas vascos, como «antiespañoles». ${ }^{67}$

En las elecciones generales de 1914, hubo un incidente relevante en Bilbao, en qué se enfrentaron republicanos y nacionalistas vascos a tiros, en el que fueron heridos dos republicanos y un guardia municipal, mientras que detuvieron «como presuntos autores» al abogado Orué y a Ramón de Belausteguigoitia (1891-1981). ${ }^{68}$

En marzo de 1915, en las elecciones provinciales hubo incidentes en Bilbao, donde volvieron a tirotearse «socialistas y bizcaitarras (éstos fueron derrotados)». En septiembre, los nacionalistas vascos ultrajaron una bandera española en Sopelana. A raíz del incidente, la Guardia Civil detuvo al periodista y dramaturgo Alfredo Echave (1872-1926). Soldevilla no entendía por qué el Gobernador civil no autorizó la celebración de un «acto patriótico» para protestar en contra del ultraje a la bandera española. ${ }^{69}$

En enero de 1916, el Gobierno designó alcalde de Bilbao al bizcaitarra Mario de Arana (1883-1931). Soldevilla aseguraba que «muy censurado fue este nombramiento, cuyos resultados se habían de ver muy pronto», ya que sus correligionarios se «entregan a sus antiguos excesos», con una pelea por divergencias políticas que finalizó con diversos detenidos. Todos, excepto uno, fueron puestos en libertad: «iYa lo creo! Como que tenían el padre Alcalde; es decir, enemigo de España». ${ }^{70}$

67 EAP, 1911, pp. 6-7, 42, 79-80 y 398-399. Mees, 2017.

68 EAP, 1915, p. 97. González-Allende, 2008, pp. 409-421.

69 EAP, 1916, pp. 132 y 425-427.

70 EAP, 1917, pp. 2-3, 7-8, 89-90. Sobre Mario de Arana véase Agirreazkuenaga, 2003, pp. 215-250. 
En enero de 1917, Cambó impulsaba la propaganda regionalista en el País Vasco, y Soldevilla afirmaba que «sus doctrinas (para nosotros de disolución nacional)» eran negativas por afirmar que los vascos tendrían que seguir el ejemplo de los catalanistas y reivindicar su personalidad. Una propuesta que para Soldevilla sería antiespañola. El líder del regionalismo catalán también hizo un mitin en Donostia que, desde la perspectiva objetiva del recopilador de El Año Político sería un ejemplo de cómo «iban estos hombres por todas partes atizando la discordia y laborando por el desmembramiento de la Nación española, a ciencia y paciencia de los Gobiernos que, ante este problema, siempre se mostraron cobardes». En mayo, diputados y concejales vascos visitaron Barcelona y confraternizaron con los catalanistas. En un ejemplo que: «los nacionalistas no dejaban de laborar». En julio de 1917, las tres Diputaciones vascas eran partidarias de solicitar la autonomía para el País Vasco. ${ }^{71}$ Un proyecto al que Soldevilla se oponía totalmente.

Se mostró muy crítico con que se validase el escaño del diputado bizcaitarra Ramón Sota. Consideraba a los nacionalistas vascos separatistas, aunque afirmasen que: «aspiramos a que nos restablezcan las facultades legislativas anteriores a 1839», cuando había sido anulada por el Gobierno español la «independencia del pueblo vasco», tal como explicaron en la petición de ayuda que enviaron al presidente norteamericano Wilson. ${ }^{72}$

\section{«Con la vida no pagarían estos hombres el daño que han hecho a la Nación». La propuesta de la autonomía catalana}

El substituto de Prat de la Riba en la presidencia de la Mancomunitat fue el arquitecto, matemático, historiador del arte y dirigente de la Lliga Josep Puig i Cadafalch. Durante la Gran Guerra buena parte de las clases medias catalanistas habían apostado por la victoria de los Aliados y, en especial, de Francia en su lucha contra los Imperios Centrales. La aliadofilia catalanista no cesó de publicitar a lo largo de la guerra que un nutrido número de catalanes luchaba en las filas de la Legión Extranjera

${ }^{71}$ EAP, 1918, pp. 37-39 113-114, 129-130, 169-170, 303-304, 368 y 456. La demanda de autonomía en Fusi, 1979-1980, pp. 94-96.

${ }^{72}$ EAP, 1919, pp. 122-123, 130-131, 143, 302, 311, 314-315, 325, 394, 431, 440-442 y 460-461. Núñez, 1995, pp. 243-275. 
francesa con el objetivo de liberar Francia y a la propia Cataluña. Regionalistas, republicanos catalanistas y separatistas, cada uno por su cuenta, intervinieron en diferentes entidades diplomáticas, políticas o culturales, para defender la causa catalanista. Esperaban que recompensaran la fidelidad aliadófila de Cataluña con su apoyo a su proyecto de conseguir el autogobierno catalán. ${ }^{73}$

Las críticas contra la Mancomunitat de los centralistas continuaron con la misma virulencia, especialmente, cuando propusieron que se aprobase la autonomía catalana. Des de la perspectiva de los españolistas, los catalanistas combatirían la tradicional nacionalidad española, y la autonomía sería una propuesta de unos políticos ambiciosos que cuestionaría la «unidad y la vida de la Patria española. Con la vida no pagarían estos hombres el daño que han hecho a la Nación con sus tolerancias y sus flaquezas». Para los nacionalistas españoles el autonomismo sería «separatismo claro». En Barcelona, se produjo un choque de nacionalismos con diversos enfrentamientos con muchos heridos y la muerte de una mujer. La Lliga impulsó la campaña para conseguir la autonomía catalana, en la que comprometieron buena parte de su prestigio y fracasaron.$^{74}$ En esta coyuntura de crispación por la movilización catalanista, se añadía el enfrentamiento entre la patronal y los obreros, especialmente los vinculados a la CNT, en el período conocido como el pistolerismo. $^{75}$

El 27 de abril de 1920, el mariscal francés Joseph Joffre visitó Madrid. Los catalanistas lo presentaban como un héroe catalán por haber nacido en la población de Rivesaltes en la Cataluña francesa. Soldevilla reconocía que su visita «fue gestionada por los catalanistas, para tener pretexto de llevar a cabo en Barcelona manifestaciones separatistas. Para quitarle este carácter, el Mariscal vino antes a Madrid» por las presiones

73 Sobre la percepción de la Gran Guerra entre las clases medias catalanas las obras de Martínez, 1988, y 1989, pp. 203-217. Sobre la participación militar de catalanes en la Gran Guerra: Esculies y Martínez, 2014. a y 2014b, pp. 109-114.

${ }^{74}$ EAP, 1918, pp. 370-404, 411-423, 447-452 y 456-459. 1919, pp. 1-2, 12-13, 21-22, 35, 48, 115-116, 220, 241-242, 261-264, 293-296, 310, 348-352, 356, 364-366, 374, 380384, 386-387, 394, 396-398, 401-406, 409-438, 455, 439-440, 453-454, 456-458, 461-462, $471-472$ y 479.1920 , pp. $68-70$ y 73. 1921, pp. 21 , 43, 55-56, 60, 70, 92-95, 97-99, 135$138,143-144,175-176,179$ у 205. 1922, pp. 233-254 у 451. 1923, pp. 233-254, 331-333, 413-418 y 430-431. 1924, pp. 4-6. Sobre el proyecto de Estatuto de Autonomía véase Balcells, 2010; Ucelay-Da Cal, 1987, pp. 93-139, y Ehrlich, 2004, pp. 271-304.

75 León, 1981. Bengoechea, 1998. Rosenthal, 2008. Balcells, 2009. 
del Gobierno español. El 1 de mayo, «a pretexto de que es de raza catalana francesa el mariscal Joffre, los separatistas catalanes, con el antiespañol Puig y Cadafalch a la cabeza organizaron una expedición de dicho General a Barcelona durante los juegos florales, más que para obsequiarle a él, para producir actos antipatrióticos y algaradas separatistas». Cuando llegó a Barcelona, «el escándalo promovido por los citados separatistas no tuvo límites. Por todas partes no hubo más que Segadors y visca $\mathrm{Ca}$ talunya lliure; es decir, Cataluña libre. Pero lo más grave fue lo ocurrido en la recepción del palacio llamado de la Generalidad (nombre antiguo), o sea el domicilio de la Mancomunidad». Se oyó un muera España y los vivas se limitaron a Cataluña y a Francia. Soldevilla conocía el patriotismo de las autoridades españolas que estaban presentes en el palacio de la $\mathrm{Ge}$ neralitat, pero: «creemos que en aquel momento estuvieron demasiado prudentes. Debieron matar en el acto al que así ofendía a España en momento tan solemne. Porque... ¿qué hubiera pasado? Nada. ¿Qué era un hecho fuera de la reglamentación y la disciplina? ¿Y qué? Por un acto semejante fueron héroes Daoíz y Velarde, y contribuyeron a la salvación de España». La visita del mariscal a Cataluña se caracterizó por «tumultos, escándalos, cargas y detenciones». ${ }^{76}$

Soldevilla pensaba que el mariscal: «no se portó correctamente. O fue a Barcelona engañado, o a sabiendas de lo que se proponían los separatistas», es decir, para los nacionalistas españoles la mera reivindicación de la existencia de Catalunya, así como de la voluntad de autogobierno, y la reafirmación de su cultura, a la que no identificaba como española, serían actos separatistas. Hasta el punto que un militar francés, nacido en la Cataluña francesa, al que se honoraba como a salvador de Francia, durante la primera Guerra Mundial, tendría que haberse retirado: «en el acto ante las primeras manifestaciones antiespañolas que llegaron a sus oídos». También consideraba censurable el «acto antipolítico de contestar en catalán al discurso del Sr. Puig y Cadafalch. Seguramente, si el mariscal Joffre hubiese ido a Irlanda, y el jefe de los separatistas le hubiese hablado en dialecto irlandés, el Mariscal no le habría contestado. ¿Por qué no obró así en Barcelona?».77

Soldevilla aplicaba el criterio que cualquier lengua que no fuese la oficial de un Estado era un dialecto. Planteamiento que utilizaba tanto

76 EAP, 1921, pp. 60, 70, 92-95, 97-99.

77 Ibidem, pp. 99-101 y 109. S. A., 1 de mayo de 1920, pp. 1-7. S. A., núms. 2147 y 2148, 30 de abril y 7 de mayo de 1920, pp. 225-240 y 241, 246, 254 y 256. 
para el catalán, como para el vasco o el gaélico irlandés. Ni tan solo se planteó que un mariscal francés no tenía ningún motivo para no utilizar su lengua materna en la Cataluña que forma parte de España. Los puntos de vista expresados por Soldevilla en estos acontecimientos eran netamente españolistas y no tenían nada de imparciales. De hecho, defendía de manera nítida su nacionalismo separador y excluyente de los que no compartían su visión de España. En El Año Político recogió artículos que llegaron a exigir el encarcelamiento del presidente de la Mancomunitat Josep Puig i Cadafalch, y alabar la cordura de los militares acuartelados en Barcelona por no haber destruido el palacio de la Generalitat a cañonazos. La polémica hizo que el diputado en el Congreso y regidor socialista en el ayuntamiento de Madrid Andrés Saborit afirmase, en el pleno municipal, que: «no nos hacemos solidarios - dijo - de lo manifestado por el Sr. Reglero, pues antes lo haríamos con lo que gritaron «iMuera España!»», con lo que se inició un gran altercado. ${ }^{78}$

El incremento de la inestabilidad política por la violencia terrorista que enfrentaba, principalmente en Barcelona, a los pistoleros anarquistas con las fuerzas de orden público y los pistoleros de la patronal. Así como, la pérdida de casi todo el protectorado español en Marruecos, después de la derrota de Annual, en $1921 .{ }^{79}$ Era una situación propicia para que los partidarios de hacer limpieza defendiesen la necesidad de un cirujano de hierro y encontraron al candidato adecuado en el capitán general de Cataluña, Miguel Primo de Rivera. Inicialmente, el dictador tuvo el apoyo de la Lliga y no suprimió la Mancomunitat, pero los catalanistas moderados, como Puig y Cadafalch rompieron con la dictadura cuando se dieron cuenta que ésta se fundamentaba en el nacionalismo español para impulsar su proyecto supuestamente regeneracionista. ${ }^{80}$

Durante el último período de la Mancomunitat, ésta fue dirigida por políticos fieles a la dictadura y explícitamente nacionalistas españoles. El

78 EAP, 1921, pp. 111, 127, 184-185, 210-214, 236, 246-247, 249-251, 257, 264-266. S. A., 31 de julio y 7 de agosto de 1920 , pp. 1 y 4 .

79 EAP, 1920, pp. 11-16, 23, 25-34, 46-55, 58-61, 64, 68-70, 73, 82-84, 140-141, $162-$ 163 y 291-292. 1921, pp. 1, 3-8, 23 i 43-48. Soldevilla, 1922, pp. 27-28, 34, 36-39, 42, 60-64, 68-69, 77, 86-89, 96, 104-105, 117-120, 127, 129, 133-137, 142-146, 150-152, 156, 160-161 , 176, 190, 192-193, 200, 205-206, 215, 225, 355-356 y 450-451. Garriga, [1987], pp. 243-249 y 253-259. Balcells, 2009.

${ }^{80}$ EAP, 1924, pp. 292-339, 441-443 y 470-473. Soldevilla, 1925, pp. 6-8. Garriga, [1987], pp. 260-265. 
nuevo presidente era Alfonso Sala Argemí, conde de Egara que era considerado por Soldevilla como un «gran catalán españolista». Acusaron a los anteriores gobiernos de la Mancomunitat de mala gestión, destruyeron gran parte de su actividad educativa, y la limitaron a aquello que establecía la ley de Mancomunidades: un ente puramente administrativo, ya que distorsionaba simbólicamente la Administración española y, finalmente, decidieron suprimirla, porque los sectores más recalcitrantes del nacionalismo español pensaban que su mera existencia cuestionaría la unidad nacional. ${ }^{81}$

\section{«Aprovechando el torbellino levantado por Cataluña, reclamaban sus fueros». El nacionalismo vasco y el mal ejemplo catalán}

Soldevilla estaba indignado, ya que consideraba que el ejemplo «disgregador que había dado Cataluña, mejor dicho los catalanistas, había ido echando raíces por varias de las antiguas regiones de España, clamando cada cual por una autonomía más o menos exagerada, que, aun, cuando se contuviera en esos límites, siempre perjudicaba a la fortaleza, a la unidad de la nación española, pues que todas tendían a vivir con una cierta separación, con más o menos total apartamiento de las restantes provincias; y aunque todos protestaban, al comienzo de sus propagandas, de su acendrado amor a España, surgía una diversificación del lenguaje, de costumbres, de leyes» que para los nacionalistas españoles, como Soldevilla, llevaría a España a la situación a la que «puso término el patriotismo y la sabia política de los Reyes Católicos». Consideraba que la propaganda había tenido éxito, porque: «iEs tan grato al habitante de cada región oír que su lengua, sus costumbres y sus leyes son las mejores del Reino, y que toda su desgracia consiste en hallarse unida a otras provincias». En el País Vasco el movimiento nacionalista tendría su base entre los vizcaínos que «aprovechando el torbellino levantado por Cataluña, reclamaban sus fueros. Bien que declarándose muy españoles, a excepción de unos cuantos vizcaínos, protegidos por un famoso naviero. Que hacían manifestaciones absolutamente antiespañolas».82 El naviero era Ramón de la Sota.

${ }^{81}$ EAP, 1925, pp. 33, 60, 85, 97, 104, 142, 149, 156, 163-164, 309-310, 424-425, 473 y 476-478. 1926, pp. 29, 44, 63-65, 121-122, 124-127, 145 y 158. Garriga, [1987], pp. 266276. Roig, 1992, y Ucelay-Da Cal, 1987, pp. 179-243.

${ }^{82}$ EAP, 1919, pp. 237-240, 394 y 440-442. 
El proyecto de Estatuto vasco quedó abortado en la Comisión extraparlamentaria. En este período, Soldevilla acusaba a los nacionalistas vascos de controlar a los jesuitas. También remarcó que Ramón de la Sota fue suspendido como diputado provincial, aunque éste no era el naviero, y la participación de Alfonso XIII en los tres primeros congresos de la Sociedad de Estudios Vascos-Eusko Ikaskuntza. ${ }^{83}$

En esta coyuntura, los catalanistas buscaron el apoyo de los nacionalistas vascos y gallegos. Soldevilla afirmaba que «los separatistas nacionalistas» formaron la triple alianza ${ }^{84}$ en un acto presidido por Antoni Rovira i Virgili (1882-1949) en el que se dieron vivas a la República del Rif. Soldevilla era un liberal contrario a la dictadura, pero como nacionalista español apoyó el decreto contra el separatismo promulgado por el gobierno del general Primo de Rivera. ${ }^{85}$

\section{A modo de conclusiones}

El Año político era un dosier político de prensa seleccionado por Fernando Soldevilla. Éste inició su obra resaltando su imparcialidad, pero cuando se trataba de explicar que proponían los nacionalismos subestatales su relato resultaba muy parcial. A lo largo de las páginas de este anuario encontramos reflejadas de manera nítida la concepción que tenía de España como nacionalista español. De hecho, el nacionalismo español puede ser visto como una manifestación del problema de la nacionalización española, entendiendo que es una de las más complejas de la Europa contemporánea.

Soldevilla era un liberal clásico que tenía una visión jacobina del estado, en la cual no tenían cabida los nacionalismos subestatales. Por ello, se muestra extremadamente duro con los que considera sus enemigos, como el doctor Bartomeu Robert, Sabino Arana o Enric Prat de la Riba de los que consideraba que hubiese sido mejor para su idea de España que no hubiesen existido, y explicitó que era partidario de matar a quien gritase un muera España en un acto público.

${ }^{83}$ EAP, 1920, pp. 10, 20 у 189. 1921, pp. 167-169 у 255-256. 1922, p. 255. 1923, pp. 290-293. S. A., 1919, y S. A., 1920. S.A., 1923. La Sociedad de Estudios VascosEusko Ikaskuntza ha sido ampliamente estudiada por Estornés, 1983 y 1990.

${ }^{84}$ Estévez, 1991.

85 EAP, 1924, pp. 115-116, 287-288 y 337-338. 
Criticó hasta la saciedad la supuesta mala gestión de los catalanistas desde la Mancomunitat. De hecho, esta crítica tenía un sentido muy claro, ya que como funcionario del estado defendía corporativamente su espacio de trabajo y de gestión frente a la función pública mancomunitaria. Sin embargo, su acceso a la dirección de la Inspección Mercantil y de Seguros del Estado, posiblemente, se debió a su vinculación al Partido Liberal.

Para Soldevilla los nacionalismos subestatales eran movimientos particularistas, aldeanos, insolidarios o infantiles, mientras que España, a la que identificaban con Castilla y con la lengua castellana, respondería a valores generales, universalistas y supuestamente solidarios. Entendía el centralismo político y el uniformismo cultural como una proyección de la modernidad y de la eficacia de los grandes estados. Ahora bien, este discurso sobre la modernidad centralista conducía, a su vez, a una retórica de carácter esencialista en la que se sublimaba la idea de España una, porque entendían que España no era sólo un Estado, sino también una nación. En cambio, para los partidarios de los nacionalismos subestatales España era un Estado, pero plurinacional. Para Ortega y Gasset se trataba de un problema irresoluble que sólo podía conllevarse. La versión más extremista de esta percepción del nacionalismo español se conjugó entre los franquistas, como una fusión del nacionalismo centralista y de la tradición religiosa católica de corte autoritario.

\section{Bibliografía}

AgiRReaZkuenaga, Joseba (dir.), Bilbao desde sus alcaldes. Diccionario biográfico de los alcaldes de Bilbao y gestión municipal, en tiempos de revolución democrática y social. Vol. 2: 1902-1937, Área de Cultura y Turismo del Ayuntamiento de Bilbao, Bilbao, 2003.

Álvarez JunCo, José, Mater Dolorosa. La idea de España en el siglo XIX, Madrid, Taurus, 2001.

AMERSFOORT, Hans van y KNIPPENBERg, Hans (eds.), States and nations. The rebirth of the «nationalities question» in Europe, Universiteit van Amsterdam, Amsterdam, 1991.

ANDERSON, Benedict, Imagined communities. Reflections on the origin and spread of nationalism, Verso, London, 1991.

AntXustegi Igartua, Esteban, El Debate nacionalista. Sabino Arana y sus herederos, Universidad de Murcia, Murcia, 2007.

Arana GoIrI, Sabino, Obras completas de Sabino Arana Goiri, Sendoa, San Sebastian, 1980 . 
Arana GoIri, Sabino, El Pensamiento de Sabino de Arana y Goiri a través de sus escritos. Antología de textos (1893-1903), Euzko Alderdi Jeltzalea = Partido Nacionalista Vasco, [Bilbao], 1995.

Augusteisn, Joost y Storm, Eric (eds.), Region and state in nineteenth-century Europe. Nation-building, regional identities and separatism, Palgrave Macmillan, New York, 2012.

Bacigalupe, Carlos, «"El intruso”, la novela bilbaína de Blasco Ibáñez, fue también pieza teatral», Bilbao. http://www.bilbao.eus/bld/bitstream/ handle/123456789/33965/38.pdf?sequence=1 [Consultado 28 de febrero de 2017, 16:04.].

Balcells, Albert, Pujol, Enric y Sabater, Jordi, La Mancomunitat de Catalunya i l'autonomia, Institut d'Estudis Catalans, Barcelona, 1996.

BALCELlS, Albert, El Pistolerisme. Barcelona (1917-1923), Pòrtic, Barcelona, 2009.

BALCELLS, Albert, El projecte d'autonomia de la Mancomunitat de Catalunya de 1919 i el seu context històric, Parlament de Catalunya, Barcelona, 2010.

BALCElls, Albert, La Mancomunitat de Catalunya, 1914-1925. El primer pas vers l'autogovern des de la desfeta de 1714, Barcelona, Diputació de Barcelona, 2014.

Bassols Coma, Martín, Las mancomunidades provinciales entre la descentralización y el regionalismo: la Mancomunidad catalana, 1914-1925, Madrid, Fundación Democracia y Gobierno Local, 2014.

BENGOECHEA, Soledad, El locaut de Barcelona (1919-1920), Curial, Barcelona, 1998.

BILlig, Michael, Banal nationalism, Sage, London-Thousand Oaks, Calif., 1995.

Calmoun, Craig, Nations matter. Culture, history, and the cosmopolitan dream, Routledge, London, New York, 2007.

Calvo, Juan Jacob, La Capitanía General de Catalunya de 1875 a 1931: la actuación de los capitanes generales, Tesis doctoral, Barcelona, UB, 1974.

CAMPo SÁnchez, Carlos, «Eduardo Sanz y Escartín: el reformismo de un católico conservador», Miscelánea Comillas. Revista de Ciencias Humanas y Sociales, vol. 69, núm. 134, 2011, pp. 177-205.

Casals, Xavier, «Auge y declive del "partido militar" de Barcelona (18981936)»,Iberic@l, número 4, en http://iberical.paris-sorbonne.fr/wp-content/ uploads/2013/10/004-14.pdf [consultado el 27 de julio de 2016].

COAKLEY, John (ed.), The Social origins of nationalist movements. The contemporary west European experience, Sage, London, 1992.

Colomines, Agustí, «Remors i negacions. El catalanisme regeneracionista a les Corts espanyoles a les albors del segle XX», Diversos Autores, Miscel.lània d'homenatge a Josep Benet, P.A.M., Barcelona, 1991.

Colomines, Agustí, El catalanisme i l'Estat. La lluita parlamentària per l'autonomia, 1898-1917, PAM, Barcelona, 1993.

Colomines, Agustí y Madaula, Aurora, Pàtria i progres. La Mancomunitat de Catalunya, 1914-1924, Comanegra, Barcelona, 2014. 
Confino, Alon, The Nation as a local metaphor. Württemberg, imperial Germany, and national memory, 1871-1918, University of North Carolina Press, Chapel Hill, 1997.

Corcuera Atienza, Javier, La Patria de los vascos. Orígenes, ideología y organización del nacionalismo vasco (1876-1903), Taurus, Madrid, 2001.

DARDÉ, Carlos, «El españolismo de los conservadores», en Morales Moya, Antonio, Fusi AIZPurúa, Juan Pablo y Blas GuerRero, Andrés de (dirs.), Historia de la nación y del nacionalismo español, Galaxia Gutenberg Círculo de Lectores, Barcelona, 2013.

Durán Solà, Lluís, Breu història del catalanisme, 2 vols., Abadia de Montserrat, Barcelona, 2009.

Elorza, Antonio, Tras la huella de Sabino Arana. Los orígenes totalitarios del nacionalismo vasco, Temas de hoy, Madrid, 2005.

EhrLICH, Charles E., Lliga Regionalista. Lliga Catalana, 1901-1936, Barcelona, Institut Cambó, Alpha, 2004.

Esculies, Joan y MarTínez Fiol, David, 12.000! Els catalans a la Primera Guerra Mundial, Ara llibres, Barcelona, 2014a.

Esculies, Joan y MARTíNEZ Fiol, «Els catalans a la Gran Guerra: un mite que perdura», en FANÉs, Félix y MingUet, Joan M. (eds.), Barcelona, zona neutral 1914-1918, Fundació Joan Miró, Barcelona, 2014b.

Estévez, Xosé, De la Triple Alianza al Pacto de San Sebastián (1923-1930). Antecedentes de Galeuzca, Universidad de Deusto. Facultad de Filosofía y Letras, San Sebastián, 1991.

Estornés Zubizarreta, Idoia, La Sociedad de Estudios Vascos. Aportación de Eusko-Ikaskuntza a la cultura vasca (1918-1936), Sociedad de Estudios Vascos, Bilbao, 1983.

Estornés ZubiZARRETA, Idoia, La Construcción de una nacionalidad vasca. El autonomismo de Eusko-Ikaskuntza (1918-1931), Sociedad de Estudios Vascos, San Sebastián, 1990.

EZKERRA, Iñaki, Sabino Arana, o, La sentimentalidad totalitaria, Belacqua, Barcelona, 2003.

ForNer MuÑoz, Salvador, Canalejas y el Partido Liberal Democrático (19001910), Madrid, Cátedra, 1993.

Fusi AizPuRua, Juan Pablo, «El problema vasco: de los Fueros al Estatuto de Guernica», Revista del Departamento de Derecho Político, núm. 5, Invierno 1979-1980, pp. 94-96.

GABRIEL, Pere, El Catalanisme i la cultura federal. Història i política del republicanisme popular a Catalunya el segle XIX, Fundació Josep Recasens, [Reus], 2007.

Garriga i Massó, Joan, Memòries d'un liberal catalanista. 1871-1939, Edicions 62, [Barcelona], [1987], pp. 139-140.

GELLNER, Ernest, Nations and nationalism, Basil Blackwell, Oxford, 1983. 
GonZÁLEZ-Allende, Iker, «El imperialismo espiritual de Ramón de Belausteguigoitia: América y España en el pensamiento de un nacionalista vasco», en Ascunce, José Ángel (ed.), El exilio. Debate para la historia y la cultura, Saturrarán, Donostia, 2008.

Granja Sainz, José Luis de la, Ángel o demonio. Sabino Arana. El patriarca del nacionalismo vasco, Tecnos, Madrid, 2015.

HERnÁNDEZ, Xavier y PINYOL, Josep, L'exèrcit contra Barcelona, Barcelona, Llibres de l'Índex-ACER, 2000

HoBSBAWM, Eric J., Nations and nationalism since 1780. Programme, myth, reality, Cambridge University Press, Cambridge, 1990.

Hroc, Miroslav, «Real and Constructed: The Nature of the Nation», HaLL, John A. (ed.), The State of the nation. Ernest Gellner and the theory of nacionalism, Cambridge University Press, Cambridge, 1998.

IzQUIERDO, Santiago, La Primera victòria del catalanisme polític. El triomf electoral de la candidatura dels «quatre presidents» (1901), Pòrtic, Barcelona, 2002.

IzQUIERDO, Santiago, El Doctor Robert (1842-1902). Medicina i compromís polític, Proa, Barcelona, 2002.

JENKINS, Brian y SOFOS, Spyros A. (eds.), Nation and identity in contemporary Europe, Routledge, London, 1996.

LEón, Ignacio, Los años del pistolerismo. Ensayo para una guerra civil, Planeta, Barcelona, 1981.

LePINA, Antonio F., «"Los veteranos del periodismo”. Charla con Fernando Soldevilla», El Imparcial, núm. 21.513, 18 de abril de 1929, p. 3.

MartíneZ FIOL, David, El catalanisme i la Gran Guerra (1914-1918). Antologia, Edicions de la Magrana/ Diputació de Barcelona, Barcelona, 1988.

MARTíNEZ FIOL, David, «L'actitud francòfila del republicanisme català durant la Primera Guerra Mundial (1914-1918): Una herència de la revolució francesa. L'exemple de Màrius Aguilar», en Revolució i socialisme, vol. II: Comunicacions, Departament d'Història Moderna i Contemporània UAB-Institut Francès de Barcelona-Fundació Caixa de Catalunya, Barcelona, 1989, pp. 203-217.

MARTínEZ FIOL, David, «Creadores de mitos. El «onze de setembre de 1714» en la cultura política del catalanismo», Manuscrits, núm. 15, 1997, pp. 341-361.

MARTíNEZ FIOL, David, «La construcción mítica del «Onze de setembre de 1714» en la cultura política del catalanismo durante el siglo XX», Historia y política, núm. 14, 2005, pp. 219-241.

MEDINA, Jaume, L'anticatalanisme del diari ABC (1916-1936), Publicacions de l'Abadia de Montserrat, Barcelona, 1995.

MEES, Ludger, «El nacionalismo vasco entre 1903 y 1923», http://www. euskomedia.org/PDFAnlt/vasconia/vas17/17113140.pdf [consultado 3/10/2017]. 
Milán, José Ramón, Sagasta o el arte de hacer política, Biblioteca Nueva, Madrid, 2001.

MiLÁn, José Ramón, «La revolución entra en palacio. El liberalismo dinástico de Sagasta», Berceo, núm. 139, 2000, pp. 93-122.

Moreno Luzón, Javier, «Nacionalizar la Monarquía. Proyectos, logros y fracasos del Partido Liberal (1898-1913)», en CABRERA, Mercedes y MORENO LuZÓN, Javier (eds.), Regeneración y reforma. España a comienzos del siglo XX, Fundación BBVA, Madrid, 2002.

Moreno LuZÓN, Javier, «El españolismo de los liberales monárquicos en el reinado constitucional de Alfonso XIII», en Morales MoYA, Antonio, FusI Aizpurúa, Juan Pablo y Blas Guerrero, Andrés de (dirs.), Historia de la nación y del nacionalismo español, Galaxia Gutenberg Círculo de Lectores, Barcelona, 2013.

Monereo Pérez, José Luis, El catolicismo social conservador. Eduardo Sanz y Escartín, Editorial Comares, Granada, 2010.

NAVARRA ORdoño, Andreu, La Región sospechosa. La dialéctica hispanocatalana entre 1875 y 1939, UAB Servei de Publicacions, Bellaterra, 2012.

NúÑEZ SEIXAS, Xosé Manoel, Internacionalitzant el nacionalisme. El catalanisme polític i la qüestió de les minories nacionals a Europa (1914-1936), Afers, Catarroja, 2010.

NúÑEZ SEIXAS, Xosé Manoel, «¿Protodiplomacia exterior o ilusiones ópticas? El nacionalismo vasco, el contexto internacional y el Congreso de nacionalidades europeas (1914-1937)», Cuadernos de Sección. Historia-Geografía, núm. 23, 1995, pp. 243-275.

OSSORIO Y BERNARD, Manuel, «Soldevilla (Fernando)», Ensayo de un catálogo de periodistas españoles del siglo XIX, Imprenta y litografía de J. Palacios, Madrid, 1903.

Pich i Mituana, Josep, Federalisme i catalanisme. Valentí Almirall $i$ Llozer (1841-1904), Eumo, Vic, 2004.

Pich i Mitjana, Josep, Contreras Ruiz, José y Pastrana Piñero, Juan, «A sangre y fuego. Antonio Royo Villanova, maestro de administrativistas y de anticatalanistas», Historia Contemporánea, núm. 51, 2015, pp. 609-640.

Pich i Mitjana, Josep, «La Revolución de Julio de 1909», Hispania. Revista Española de Historia, núm. 249, 2015, pp. 173-206.

RIQUER, Borja de, «Els corrents conservadors catalans i la seva evolució cap el catalanisme polític», L’Avenç, núm. 100, Barcelona, 1987, p.78.

RIQUER, Borja de, «El govern Silvela-Polavieja i l'opinió pública barcelonina. Crònica d'un distanciament», L'Avenç, núm. 239, Barcelona, 1999, pp. 46-51.

RIQUER, Borja de, Escolta, Espanya. La cuestión catalana en la época liberal, Marcial Pons, Madrid, 2001.

Risques, Manel, L'Estat a Barcelona. Ordre públic i governadors civils, Base, Barcelona, 2012. 
RoIg i Rossich, Josep Maria, La Dictadura de Primo de Rivera a Catalunya. Un assaig de repressió cultural, P.A.M., Barcelona, 1992.

Roig I Rossich, Josep Maria, «La Mancomunitat de Catalunya. Un primer pas», Revista de Catalunya, 2014.

Romero Maura, Joaquín, La Rosa de Fuego. Republicanos y anarquistas. La política de los obreros barceloneses entre el desastre colonial y la Semana Tràgica, 1899-1909, Grijalbo, Barcelona, 1975.

Rosenthal, David H., Banderes al vent!. La Barcelona de les utopies, 19141936, Barcelona, Meteora, 2008.

Rubí, Gemma y Espinet, Francesc (eds.), Solidaritat catalana i Espanya (19051909), Base, Barcelona, 2008.

RuIZ TORRES, Pedro, «Las repercusiones de los cambios culturales de la modernidad en el modo de pensar la biografía», Ayer, núm. 93, 2014, pp. 19-46.

S.A., «Sesión del Congreso», $A B C, 28$ de junio de 1895, p. 5.

S.A., «Rasgos de la jornada. Apoteosis de Don Niceto», $A B C, 29$ de junio de 1912, p. 9.

S.A., $A B C, 4$ de enero de 1913, p. 12.

S.A., «Audiencia regia», $A B C, 30$ de marzo de 1924, 29 de mayo de 1927 y 16 de junio de 1928, pp. 16, 24 y 21.

S.A., La Campana de Gràcia, núms. 2655, 2668 y 2669, 1 de mayo de 1920, 31 de julio y 7 de agosto de 1920 pp. 1-7, 1 y 4.

S.A., L'Esquella de la Torratxa, núms. 2147 y 2148,30 de abril y 7 de mayo de 1920 , pp. 225-240 y 241, 246, 254 y 256.

S.A., Primer Congreso de estudios vascos. Recopilación de los trabajos de dicha asamblea, celebrada en la Universidad de Oñate del 1 al 8 de septiembre de 1918, bajo el patrocinio de las diputaciones vascas, Bilbaína de Artes Gráficas, Bilbao, 1919.

S.A., II Congreso de Estudios Vascos. Recopilación de los trabajos de dicha asamblea celebrada en Pamplona del 18 al 25 de Julio de 1920, Sociedad de Estudios Vascos, Pamplona, 1920.

S.A., III Congreso de Estudios Vascos. Recopilación de los trabajos de dicha asamblea celebrada en Guernica del 10 al 17 de setiembre de 1922, Sociedad de Estudios Vascos, San Sebastián, 1923.

S.A., «Muerte de un periodista ilustre. Ha fallecido don Fernando Soldevilla», La Época, 6 de abril de 1931

S.A., La Voz, 6 de abril de 1931.

S.A., «Fallecimiento de Fernando Soldevilla», ABC, 7 de abril de 1931, p. 33.

S.A., «Muere un ilustre periodista», La Correspondencia militar, 7 de abril de 1931.

S.A., «Muere de un periodista. Fernando Soldevilla», La Libertad, 7 de abril de 1931.

S.A., «Don Fernando Soldevilla», La Nación, 7 de abril de 1931, p. 3. 
S.A., «Fallecimiento de don Fernando Soldevilla», El Siglo Futuro, 7 de abril de 1931, p. 3.

S.A., «Escritor fallecido. Fernando Soldevilla», La Tierra, 7 de abril de 1931, p. 8.

S.A., «Don Fernando Soldevilla», El Sol, 7 de abril de 1931, p. 5.

SÁEz CoRtina, Manuel (ed.), Las máscaras de la libertad. El liberalismo español 1808-1950, Marcial Pons, Madrid, 2003.

Santolaria, Francesc, El Banquet de la Victòria i els Fets de ;Cu-Cut!, Barcelona, Meteora, 2005.

SERRANO, Carlos, «El nacimiento de los intelectuales: algunos replanteamientos», Ayer, núm. 40, 2000, pp. 11-23.

SMITH, Anthony D., The Ethnic origins of nations, Blackwell, Oxford, 1988.

SMiтh, Anthony D., The Nation in history. Historiographical debates about ethnicity and nationalism, Polity Press, Cambridge, 2000.

Soldevilla, Fernando, Matrimonios y amoríos de Alfonso XI. Opúsculo histórico, Imp. de Enrique Rubiños, Madrid, 1879.

Soldevilla, Fernando, Leyendas dramáticas, [s.e.], Madrid, 1881.

Soldevilla, Fernando, Historias de otras edades. Tradiciones en prosa, Imp. de Enrique Rubiños, Madrid, 1883.

SoldEVILla, Fernando, Joyas de la literatura española; con artículos biográficos y bibliográficos, Garnier Hermanos, París, 1884.

Soldevilla, Fernando, (recopilador) de ACUÑA, Manuel, Poesías de Manuel Acuña, Garnier Hermanos, París, 1885.

Soldevilla, Fernando, (prólogo y selección) en Jovellanos, M., Obras escogidas de Jovellanos, Garnier Hermanos, París, 1886.

SoldeVILla, Fernando, El cura loco, [s.e.], Madrid, 1887a.

SoldeVIlla, Fernando, Verdades y mentiras: (más mentiras que verdades). Poesías, con una carta-prólogo de Echegaray, J., Fernando Fe, Madrid, 1887b.

Soldevilla, Fernando, El Año político, Años I, V-VI, Imprenta de Enrique Rojas, Años VII-IX, XI-XIV, XVI-XXI, Imprenta de Ricardo Rojas, Años XXII-XXXI, Imprenta de Julio Cosano, Madrid, 1896, 1900-19011904, 1906-1909, 1911-1926.

SoldeVILla, Fernando, «La redacción y el grupo de La Veu», El Imparcial, 22 de octubre de 1899 , p. 1.

Soldevilla, Fernando, Juez y reo. Drama en tres actos y en prosa, R. Velasco, Madrid, 1900a.

Soldevilla, Fernando, La opinión en Cataluña, Tipografía de Rojas, Madrid, 1900b.

Soldevilla, Fernando, Las Cortes de Cádiz. Orígenes de la revolución española, [s.e.], [S.1.], 1910.

SoldEVILla, Fernando, Tres revoluciones (apuntes y notas). Las Juntas de Defensa, la Asamblea parlamentaria, la huelga general, Imp. de Julio Cosano, Madrid, 1917a. 
Soldevilla, Fernando (texto) y CANTó, Gonzalo (música), El Cristo de la Vega; zarzuela en tres actos y siete cuadros, en verso, Prensa Popular, Madrid, 1917b.

Soldevilla, Fernando, Los hombres de la libertad, Imp. de Julio Cosano, Madrid, 1927.

SoldeVILla, Fernando, Compendio de literatura general y de historia de la literatura española e hispano-americana desde los comienzos al siglo XX, París, Garnier Hermanos, 1930.

Torres Villanueva, Eugenio, Ramón de la Sota (1857-1936). Un empresario vasco, LID, Madrid, 1998.

Termes, Josep y Colomines, Agustí, Patriotes i resistents. Història del primer catalanisme, Base, Barcelona, 2003.

Trias Vejarano, Juan J., Almirall y los orígenes del catalanismo, Siglo XXI, Madrid, 1975.

UCELAY-DA CAL, «La Diputació i la Mancomunitat: 1914-1923» y «La Diputació durant la dictadura: 1923-1930», en RIQUER, Borja de (dir.), Història de la Diputació de Barcelona, Barcelona, Diputació de Barcelona, 1987, pp. 37-259.

UCELAY-DA CAL, Llegar a capital: Rango urbano, rivalidades interurbanas y la imaginación nacionalista en la España del siglo XX, Fundació Rafael Campalans, Barcelona, 1997.

Ugalde, Martín de, Biografia de tres figuras nacionales vascas: Arana-Goiri, Agirre, Leizaola, Sendoa, Donostia, 1984.

Ullmann, Joan Connelly, La Semana Trágica. Estudio sobre las causas socioeconómicas del anticlericalismo en España, 1898-1912, Ariel, Esplugues de Llobregat, 1972 [reeditado en Ed. B., Barcelona, 2009].

Villacorta Baños, Francisco, Profesionales y burócratas. Estado y poder corporativo en la España del siglo XIX, 1890-1923, Madrid, Siglo XXI, 1989.

\section{Financiación}

Este artículo forma parte del proyecto colectivo de investigación: «"Fisión" y "Fusión" estatales en los sistemas políticos contemporáneos: el excepcionalismo y los cambios de fronteras». HAR2015-67658-P (MINECO/FEDER, UE). También cuenta con el apoyo del Grupo de Investigación Consolidado reconocido por la AGAUR: «Grup d'Estudi de les Institucions i de les Cultures Polítiques (S. XVI-XXI)». Referència: GRC 2014 SGR 1369. Agradecemos a los Drs. Andreu Navarra Ordoño y Joan Pastrana Piñero la lectura crítica de este artículo, aunque los errores únicamente son atribuibles a los autores. 


\section{Datos de los autores}

Josep Pich i Mitjana (josep.pich@upf.edu) (Manresa, 1967) Licenciado en Geografía e Historia por la Universitat de Barcelona (1991) y en Derecho por la UNED (2005). Doctor en Historia Contemporánea por la Universitat Pompeu Fabra (1999), con la tesis: Valentí Almirall i Llozer (1841-1904) i la gènesi del catalanisme polític. Actualmente ejerzo como profesor titular de historia contemporánea en la Universidad Pompeu Fabra.

Autor de diversos libros, especialmente sobre catalanismo, capítulos de libro y de artículos en revistas especializadas.

Especialista en historia del movimiento catalanista, tanto en su vertiente política como en la cultural. Sus líneas de investigación actuales son la historia política española de la segunda mitad XIX y primera mitad del XX, así como la génesis y la evolución del federalismo, del catalanismo y del imperialismo español.

David Martínez Fiol (davidm@iesmollet.net). (Barcelona, 1962). Licenciado (1985), magister (1999). Doctor en Historia y premio extraordinario de doctorado (2006) por la Universitat Autònoma de Barcelona (UAB). Catedrático de Geografia e Historia en el Institut de Mollet del Vallès, donde ejerce de profesor desde 1990. También ejerzo de profesor Asociado en la Universidad Autónoma de Barcelona.

Vinculado a la enseñanza ha escrito libros didácticos de historia de Cataluña y el mundo. En el ámbito de la Docencia, fui profesor de Historia de Cataluña en la Escola de Policia de Catalunya durante el periodo 1990-2001.

Autor de diversos libros, especialmente sobre la Primera Guerra Mundial, capítulos de libro y de artículos en revistas especializadas. He sido coordinador de crítica bibliográfica de la revista L'Avenç (1991-1997).

Sus líneas de investigación actuales son la historia política española de la segunda mitad XIX y primera mitad del XX.

José Contreras Ruiz (jcontrerasrz@gmail.com) (1977). Licenciatura en Historia por la Universidad Autónoma de Barcelona (1999). Máster en Iniciación a la Investigación en Historia Comparada Social, Política y Cultural. Tesina: "Manuel Azaña y la política catalana» (2006). Doctor en Historia por la Universidad Pompeu Fabra (2012), con la tesis «El somriure de la política. Ninotaires al voltant de la Segona República». Tesis doctoral centrada en el estudio de las revistas satíricas españolas durante la Segunda República Española (1931-1936).

Ha publicado el libro Azaña y Cataluña. Historia de un desencuentro. Autor de capítulos de libro y de artículos en revistas especializadas.

Sus líneas de investigación actuales son la historia política española de la segunda mitad XIX y primera mitad del XX. 